\title{
Paciente con vómitos postprandiales
}

\section{A Patient Presenting with Postprandial Vomiting}

Mujer de 71 años que acude por un cuadro de 3 meses de evolución de vómitos postprandiales, sin disfagia, ni pirosis. Se acompaña de dolor epigástrico intermitente, sin irradiación, ni pérdida de apetito. Además presenta diarrea líquida de 3-4 deposiciones al día sin productos patológicos y pérdida de 10 kilos de peso. No fiebre, ni disnea, ni dolor torácico, ni aumento de tos ni expectoración. Había sido fumadora de 40 paquetes/año hasta hacía 3 meses en que había sido sometida a una lobectomía superior izquierda por vía subdiafragmática por un carcinoma epidermoide de pulmón (pT2NOM0). Presentó buena evolución postoperatoria, pero poco después de ser dada de alta tras la cirugía se inició el cuadro clínico. En la exploración física destacaba una hipoventilación en la base pulmonar izquierda. La radiografía de tórax (figura 1) mostraba presencia de gas en hemitórax inferior izquierdo sugestivo de corresponder a estómago. Se realizó una tomografía axial computarizada de tórax (figuras $2 \mathrm{~A}$ y $2 \mathrm{~B}$ ) que demostró una hernia diafragmática con ascenso del colon y del estómago con signos de retención gástrica y tracción de vasos mesentéricos, aunque sin evidencia de isquemia en la pared en ese momento. La paciente fue sometida a una toracotomía para reducción de esa hernia diafragmática con buen resultado y evolución.

Los hallazgos radiológicos en las hernias diafragmáticas son muy variables. La radiografía simple de tórax tiene una sensibilidad relativamente baja cuando no se identifica presencia de gas de morfología gastrointestinal en la cavidad torácica ${ }^{1}$. La tomografía computarizada con reconstrucciones multiplanares permite realizar el diagnóstico, identificar el contenido de la hernia y sus posibles complicaciones ${ }^{2}$. Por ello, ante un paciente con antecedentes de cirugía torácica reciente, una imagen en la radiografía de tórax con visualización de burbujas gaseosas con nivel en un hemitórax, borramiento o irregularidad del contorno del diafragma, elevación de un hemidiafragma, o desplazamiento del mediastino hacia el lado contralateral, debe hacernos sospechar la posibilidad de una hernia diafragmática². El uso de un abordaje quirúrgico subdiafragmático para la cirugía del cáncer de pulmón se ha descrito recientemente y aún no se han publicado datos acerca de la incidencia de esta complicación. El conocimiento de este tipo de abordaje es crucial para sospechar el diagnóstico en los casos con hallazgos radiológicos sutiles.

\section{Bibliografía}

1. Hirano ES, Silva VG, Bortoto JB, Barros RH, Caserta NM, Fraga GP. Plain chest radiographs for the diagnosis of post-traumatic diaphragmatic hernia. Rev Col Bras Cir. 2012; 39(4):280-5.

2. Crandall M, Popowich D, Shapiro M, West M.Posttraumatic hernias: historical overview and review of the literature. Am Surg. 2007; 73(9):845-50.

\section{Diagnóstico}

Hernia diafragmática tras cirugía torácica

por vía subdiafragmática

\section{Laura González Vázquez¹, Cármen Trinidad López²}

${ }^{1}$ Servicio de Medicina Interna, ${ }^{2}$ Servicio de Radiodiagnóstico.

Hospital POVISA. Vigo

Como citar este artículo: González Vázquez L, Trinidad López C

Hernia diafragmática tras cirugía torácica por vía subdiafragmática. Galicia Clin 2013; 74 (4): 194

Recibido: 11/4/2013; Aceptado: 10/6/2013
Figura 1. Rx de Tórax en proyección posteroanterior: elevación del hemidiafragma izquierdo con imágenes aéreas en hemitórax inferior

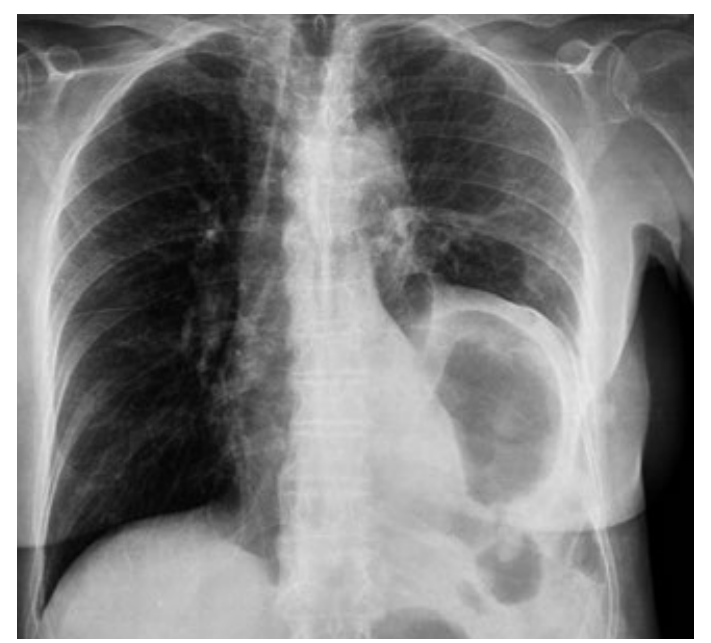

Figura 2: TC de Tórax con contraste intravenoso

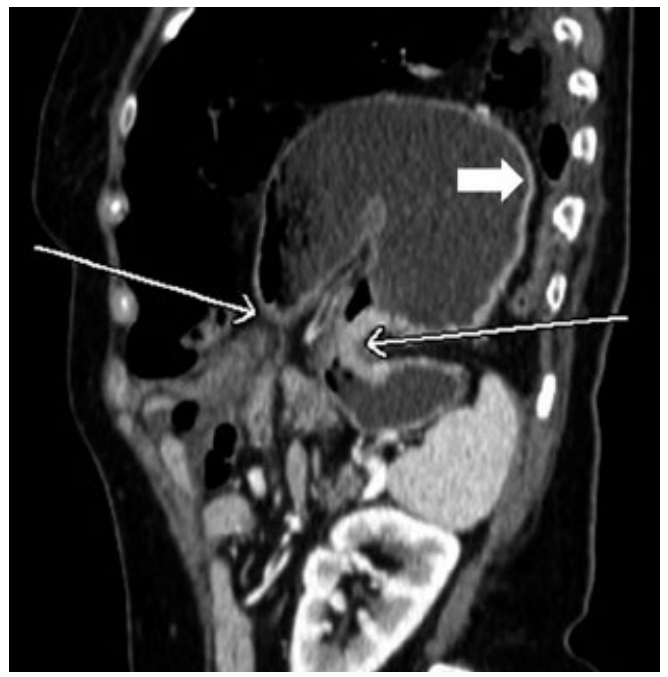

A. Reconstrucción sagital que muestra el defecto diafragmático (flechas) a través del que se hernia el cuerpo del estómago que aparece dilatado con contenido retenido en su interior observándose captación de la pared (flecha corta) que excluye isquemia

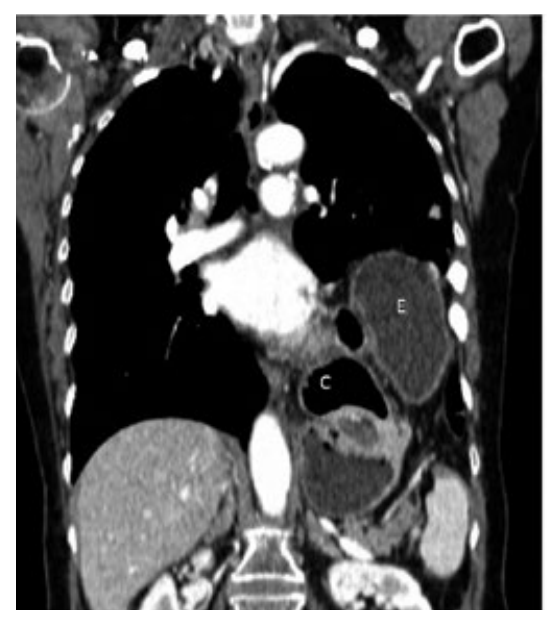

B. Reconstrucción coronal que muestra el estómago (E) y el colon (C) herniados ocupando el hemitorax inferior izdo 